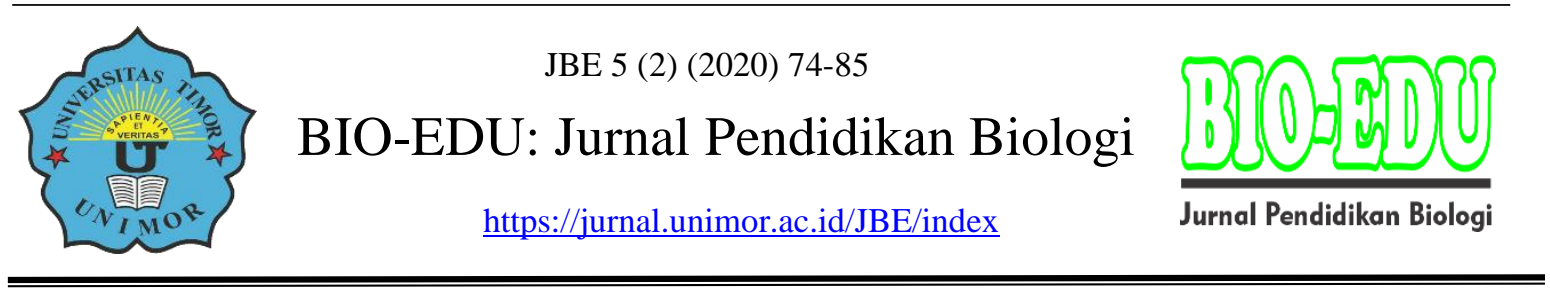

\title{
Kelimpahan Tumbuhan Paku (Pteridophyta) di Hutan Desa Tanglapui, Kecamatan Alor Timur, Kabupaten Alor
}

\author{
Johanis Mowata ${ }^{1}$, Arnold Ch Hendrik ${ }^{2}$, dan Yanti Daud ${ }^{3}$ \\ ${ }^{123}$ Program Studi Pendidikan Biologi, Fakultas Keguruan dan Ilmu Pendidikan, \\ Universitas Kristen Artha Wacana, Kupang - NTT, Indonesia, \\ E-mail: arnold hendrik@yahoo.co.id
}

DOI: https://doi.org/10.32938/jbe.v5i2.576

\begin{abstract}
Abstrak
Penelitian ini bertujuan untuk mengetahui komposisi jenis, keanekaragaman, dan kerapatan tumbuhan paku di kawasan Hutan Desa Tanglapui, Kecamatan Alor Timur, Kabupaten Alor. Untuk melakukan pengamatan dan membagi lokasi penelitian menjadi 4 stasium yaitu: stasium 1 bagian timur, stasium 2 bagian selatan, stasium 3 bagian utara, dan stasium 4 bagian barat, yang terdapat adanya tumbuhan paku (pteridophyta). Pada setiap stasium dipasang dua plot pengamatan untuk pengambilan sampel. Penempatan plot pengamatan dengan menggunakan purposive sampling dengan menentukan titik awal dan memasang plot berukuran panjang $20 \mathrm{~m}$ dan lebar $10 \mathrm{~m}$. Setiap tumbuhan paku yang ditemukan di lokasi penelitian dicatat. Data yang diperoleh kemudian diolah untuk melihat jumlah spesies paku yang ditemukan, kelimpahan masing-masing tumbuhan paku dan dihitung indeks keanekaragam tumbuhan paku menggunakan rumus keanekaragaman Shannon-Wiener. Hasil penelitian menunjukan bahwa ditemukan 22 jenis tumbuhan paku yakni Diplazium esculentum, Cyathea contaminans, Lygodium venustum sw, Drynaria quercifolia, Platycerium bifurcatum, Microsorum punctatum, Equisetum debile, Pteris biaurita L, Pytirogramma calomelanos, Polypodium virginianum L, Hymenasplenium sp, Asplenium affine, Adiantum cuneatum, Pteris cretica L, Davallia denticulate, Asplenium attenuatum, Psilotum nudum L, Marsilia polycarpa, Pteris vittata, Nephrolepis biserrata, Pyrrosia piloselloidesi L M.G, Macrothelipteris torresiana. Salah satu diantara tumbuhan paku tersebut yang mendomisi kawasan hutan tanglapui yaitu Cyathea contaminans dengan jumlah sebanyak 509 individu dengan kerapatan sebesar 0,32 individu $/ \mathrm{m}^{2}$. Nilai dari keanekaragaman di kawan hutan tanglapui rendah yaitu sebesar 0.77 .
\end{abstract}

Kata kunci: Identifikasi, Kerapatan, Keanekaragaman, Tumbuhan Paku

\begin{abstract}
This study aims to determine the composition of species, diversity, and density of ferns in the Forest area of Tanglapui Village, East Alor District, Alor Regency. To make observations and divide the study site into 4 stations, namely: stasium 1 east, stasium 2 south, stasium 3 north, and stasium 4 western parts, which contained nail plants (pteridophyta). At each station two observation plots were installed for sampling. Placement of the observation plot using purposive sampling by determining the starting point and installing a plot measuring $20 \mathrm{~m}$ long and $10 \mathrm{~m}$ wide. Every nail plant found at the study site was recorded. The data obtained is then processed to see the number of nail species found, the abundance of each fern and the index of diversity of ferns using the Shannon-Wiener diversity formula. The results showed that 22 species of ferns were found, namely Diplazium esculentum, Cyathea contaminans, Lygodium venustum sw, Drynaria quercifolia, Platycerium bifurcatum, Microsorum punctatum, Equisetum debile, Pteris biaurita L, Pytirogramma calomelanos, Polypodium virginianum sp. cuneatum, Pteris cretica L, Davallia denticulate, Asplenium attenuatum, Psilotum nudum L, Marsilia polycarpa, Pteris vittata, Nephrolepis biserrata, Pyrrosia piloselloidesi L MG, Macrothelipteris torresiana. One of the ferns that dominates the tanglapui
\end{abstract}


forest area is Cyathea contaminans with a total of 509 individuals with a density of 0.32 individuals / $\mathrm{m} 2$. The value of diversity in the lowland tanglapui forests is 0.77 .

Keywords: Identification, Density, Diversity, fern Plants

\section{PENDAHULUAN}

Desa Tanglapui merupakan salah satu desa yang terletak di Kecamatan Alor timur, Kabupaten Alor, Provinsi Nusa Tenggara Timur (NTT). Desa ini memiliki luas wilayah yang cukup besar yaitu empat ribu hektar dan mempunyai keadaan alam yang subur. Hutan Tanglapuidid ominasi oleh pepohonan yang tumbuh rapat dan subur, sehingga suhu tergolong rendah yang menciptakan suasana sejuk Desa Tanglapui. Kondisi tanah di Hutan Desa Tanglapui di dominasi rawa-rawa yang digenangi air. Kondisi ini menyebabkan tumbuh-tumbuhan tumbuh subur dan banyak dijumpai pada lingkungan tersebut (Musriadi dkk, 2017). Di wilayah ini juga terdapat lima aliran sungai permanen yang mengalir bebas dari ketinggian (pegunungan) menuju ke hulu sungai atau muara. Kawasan ini juga merupakan salah satu wilayah yang mempunyai kekayaan flora atau memiliki banyak jenis tumbuh-tumbuhan mulai dari jenis tumbuhan tingkat tinggi seperti semua tumbuhan yang berbiji. Berbagai tanaman berbiji yang ditemui di Desa Tanglapui contohnya anggur, rambutan, belimbing, jambu, pepaya, mangga, nangka, terong, tomat dan sebagainya. Juga terdapat jenis tumbuhan tingkat rendah seperti kelompok tumbuhan yang struktur tubuh dan perkembangan organ tubuhnya masih sangat sederhana contohnya tumbuhan belah (schizophyta), tumbuhan talus (thallophyta), tumbuhan lumut (bryophyta), tumbuhan paku (pteridophyta) yang terdapat di wilayah tersebut. Terdapat juga beberapa jenis hewan (fauna), baik itu hewan liar seperti rusa, babi, burung, ular, serangga.

Salah satu kelompok tumbuhan yang banyak terdapat di kawasan tersebut yaitu terdapat beberapa jenis paku-pakuan (pteridophyta) yang tersebar luas pada kawasan Hutan Tanglapui. Paku-pakuan (pteridophyta) sebagai dari keanekaragaman hayati merupakan komunitas tumbuhan yang memiliki fungsi ekologis yang cukup penting di dalam ekosistem hutan seperti sebagai vegetasi penutup tanah, pencampur serasah bagi pembentukan arah tanah. Peran tumbuhan paku lainnya yaitu sebagai sumber plasma nutfah juga berpotensi sebagai sumber pangan dan obat-obatan.

Sampai saat ini pada kawasan Hutan Tanglapui tersebut masih belum terinventarisasi jenis paku-pakuan yang hidup di hutan tersebut. Menurut Arini dan Kinho (2012) menyatakan bahwa tumbuhan paku ditemukan tersebar luas mulai dari daerah tropis hingga dekat kutub utara dan selatan. Tumbuhan paku juga dapat ditemukan daerah terbuka maupun daerah ternaungi, pada hutan primer sekunder, pinggir pantai, pegunungan, pinggir jalan maupun pada berbagai kondisi lingkungan lainnya. Karena itu tumbuhan paku diketahui memiliki keanekaragam jenis yang tinggi dan mampu hidup dalam kondisi lingkungan yang bervariasi. Sanginés-Franco et al., (2011) menyatakan di Sierra Madre Oriental, Mexico, tumbuhan paku umumnya banyak dapat ditemukan kawasan hutan campuran yang memiliki curah hujan dan kelembaban tinggi, meski bebrapa spesies juga ditemukan pada daerah aird dengan curah hujan yang rendah. Alghifari (2016), menemukan 26 jenis tumbuhan paku pada Kawasan Gunung Bunder Taman Nasional, Gunung Halimun Salak Bogor. Beberapa penelitian lain di Indonesia juga melakukan penelitiannya di pegunungan atau sungai yang memiliki ketersediaan air baik dan kelembaban yang tinggi (Syafrudin et al., 2016; Wanma, 2016; Yuliastuti et al., 2016; Imaniar, 2017). Penelitian mengenai tumbuhan paku-pakuan di NTT saat ini sudah banyak dilakukan, seperti penelitian jenis-jenis tumbuhan paku (pteridophyta) di 
Kawasan Hutan Mutis Desa Bonle'u, Kecamatan Tobu, Kabupaten Timor Tengah Selatan (TTS) (Liem, 2011), dan menemukan 17 jenis tumbuhan paku. Mulyatin (2016) menemukan 39 jenis paku-pakuan di Pulau Sumba, NTT, sedangkan Ruma dan Nomnafa (2016) menemukan 10 spesies tumbuhan paku di Oehala Desa oelekam, Kabupaten TTS.

Hutan Desa Tanglapui dengan kondisi lingkungan seperti kelembaban tinggi dan sumber mata air yang banyak memiliki jenis tumbuhan paku yang cukup banyak jenisnya. Sampai saat ini jenis-jenis tumbuhan paku dan kelimpahannya di Kabupaten Alor, khususnya di Hutan Desa Tanglapui belum dilaporkan secara ilmiah. Penelitian ini dilakukan untuk menginventarisasi jenis-jenis tumbuhan, kelimpahan tumbuhan paku dan keanekaragaman tumbuhan paku di Hutan Desa Tanglapui, Kecamatan Alor Timur, Kabupaten Alor.

\section{METODE}

\section{Waktu dan lokasi penelitian}

Penelitian ini dilakukan di Hutan Desa Tanglapui, Kecamatan Alor Timur, Kabupaten Alor pada bulan Juni sampai Juli 2019.

\section{a. Populasi dan Sampel}

Populasi dalam penelitian ini adalah semua jenis tumbuhan paku (pteridophyta). Teknik pengambilan sampel menggunakan purposive sampling adalah salah satu teknik sampling non random sampling yang mana peneliti menentukan pengambilan sampel dengan cara menetapkan ciri-ciri khusus yang sesuai dengan tujuan penelitian sehingga diharapkan dapat menjawab permasalahan penelitian. Dalam penelitian ini pengambilan sampel dilakukan pada bagian Timur, Barat, Utara dan Selatan Hutan Desa Tanglapui, agar paku tumbuhan paku yang diperoleh dapat mewakili setiap wilayah hutan.

\section{b. Desain Penelitian}

Langkah-langkah yang ditempuh dalam pengambilan data adalah sebagai berikut.

\section{Survei lapangan}

Kegiatan ini dilakukan sebagai studi pendahuluan untuk memperoleh gambaran secara umum tentang tempat keberadaan tumbuhan paku (pteridophyta) dengan faktor lingkungannya.

2. Pengambilan sampel

a. Memasang plot pada kawasan hutan Desa Tanglapui dengan cara purposive sampling, menentukan titik awal untuk melakukan pengamatan dan membagi lokasi penelitian menjadi 4 stasium yaitu: stasium 1 bagian timur, stasium 2 bagian selatan, stasium 3 bagian utara, kemudian stasium 4 dibagian barat, yang terdapat adanya tumbuhan paku (pteridophyta).

b. Pada setiap stasium dipasang dua plot sesuai gambar 1, untuk pengambilan sampel.

c. Melakukan pengambilan sampel dengan cara pemasangan plot dimulai dari stasiun 1 bagian timur, stasiun 2 bagian selatan, stasiun 3 bagian utara, kemudian stasiun 4 bagian barat.

d. Plot berukuran Panjang $20 \mathrm{~m}$, Lebar $10 \mathrm{~m}$ dan Luas petak $200 \mathrm{~m}^{2}$. 


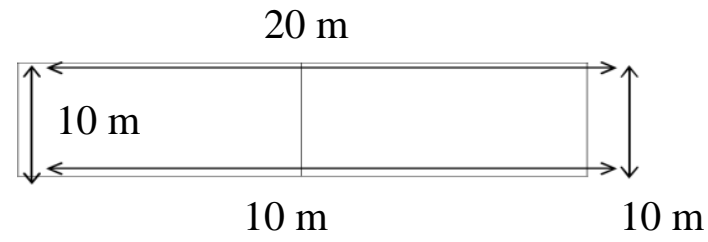

Gambar 1. Petak penelitian (Research Plot)

e. Jenis-jenis tumbuhan paku (pteridophyta) dalam kawasan garis petak tersebut dicatat nama beserta habitat dan masing-masing jumlah individu yang ada dikawasan garis petak tersebut.

f. Spesies yang belum diketahui namanya diambil semua organnya dengan cara mencabut menggunakan linggis dan di awetkan menggunakan alkohol 70\%, dimasukan dalam plastik kemudian diberi label untuk diidentifikasi di Laboratorium Pendidikan Biologi Universitas Kristen Artha Wacana dengan pedoman pada buku identifikasi paku-pakuan atau sumber lain yang relevan dengan cara deskriptif.

\section{c. Teknik Analisis Data}

Analisis data dalam penelitian ini adalah dengan menggunakan metode kualitatif dan kuantitaf.

1. Komposisi jenis

Data yang sudah diperoleh dianalisis secara deskriptif. Teknik analisis data dalam penelitian ini dilakukan dengan menentukan nama spesies atau nama tumbuhan paku (pteridophyta) yang ditemukan di Kawasan Hutan Desa Tanglapui. Menurut Simpson (2006) menyatakan bahwa teknik identifikasi dilakukan dengan beberapa cara yaitu menggunakan kunci taksonomi, mendeskripsikan berdasarkan literatur, membandingkan objek atau spesimen, membandingkan gambar, dan pendapat dari lembaga atau ahli yang berkompoten. Penelitian identifikasi dilakukan dengan menggunakan kunci identifikasi, mencocokan gambar pada Buku identifikasi paku pakuan atau sumber lain yang relevan. Identifikasi yang dilakukan dengan cara mengamati morfologi, terutama pada letak dan bentuk sorus.

2. Indeks nilai penting (INP)

Perhitungan indeks nilai penting (INP) diperoleh dengan cara menjumlahkan besaran-besaran Kerapatan Relatif (KR), dan Frekuensi Relatif (FR), dengan rumus INP $=$ Kerapatan Relatif + Frekuensi Relatif. Nilai KR dan FR :

a. Kerapatan Relatif (KR)

Kerapatan K

$$
\begin{aligned}
& =\frac{\text { Jumlah individu suatu jenis }}{\text { Luas petak pengamatan }} \\
& \text { Kerapatan Relatif } \\
& =\frac{\text { Kerapatan suatu jenis }}{\text { kerapatan seluruh jenis }} \times 100 \%
\end{aligned}
$$

b. Frekuensi Relatif

Frekuensi

$=\frac{\text { Jumlah petak ditemukannya suatu jenis }}{\text { Jumlah petak seluruhnya }}$

Frekuensi Relatif

$=\frac{\text { Fekuensi suatu jenis }}{\text { Frekuensi seluruh jenis }} \times 100 \%$ 
3. Indeks keanekaragaman jenis ( $\left.\mathrm{H}^{\prime}\right)$

Keanekaragaman jenis yang terdapat dalam komunitas dapat diketahui dari indeks keanekaragaman menurut Shannon-Wiener:

Keterangan:

$$
\mathrm{H}^{\prime}=-\sum \frac{\mathrm{ni}}{\mathrm{N}} \log \frac{n i}{N}
$$

$$
\begin{aligned}
& \mathrm{H}^{\prime}=\text { Indeks Keanekaragaman Shannon-Wiener } \\
& \text { ni }=\text { Jumlah Individu Dari Suatu Jenis } \\
& \text { N }=\text { Jumlah Total Individu Seluruh Jenis. }
\end{aligned}
$$

Besarnya Indeks Keanekaragaman Jenis menurut Shannon Wiener didefinisikan sebagai berikut:

a. Nilai H'> 3 menunjukan bahwa keanekaragaman spesies pada suatu transek adalah keanekaragaman tinggi.

b. Nilai $\mathrm{H}^{\prime} 1 \leq \mathrm{H}^{\prime} \leq 3$ menunjukan bahwa keanekaragaman spesies pada suatu transek keanekaragaman masih sedang.

c. Nilai H' $<1$ menunjukan bahwa keanekaragaman spesies pada suatu transek sedikit atau rendah.

\section{HASIL DAN PEMBAHASAN}

\section{Komposisi Jenis-Jenis Tumbuhan Paku Yang Ditemukan Di Kawasan Hutan Desa Tanglapui}

Berdasarkan hasil penelitian di Hutan Desa Tanglapui, Kecamatan Alor Timur, Kabupaten Alor, terdapat 13 famili tumbuhan paku yaitu famili Athyriaceae, Cyatheaceae, Schizaceae, Polypodiaceae, Equisetaceae, Pteridaceae, Aspleniaceae, Dryopteridaceae, Marattiaceae, Davalliaceae, Psilotaceae, Marsileaceae, dan Thelypteridaceae. Dari 13 famili terdiri 22 spesies tumbuhan paku yaitu Diplazium esculentum, Cyathea contaminans, Lygodium venustum sw, Drynaria quercifolia, Platycerium bifurcatum, Microsorum punctatum, Equisetum debile, Pteris biaurita L, Pytirogramma calomelanos, Polypodium virginianum L, Hymenasplenium sp, Asplenium affine, Adiantum cuneatum, Pteris cretica L, Davallia denticulata, Asplenium attenuatum, Psilotum nudum L, Marsilia polycarpa, Pteris vittata, Nephrolepis biserrata, Pyrrosia piloselloidesi LM.G, dan Macrothelipteris torresiana. Berdasarkan hal tersebut disimpulkan bahwa tumbuhan paku yang ditemukan di kawasan Hutan Tanglapui tergolong memiliki jumlah spesies yang lebih banyak dibandingkan dengan Liem (2011) dalam penelitiannya di Kawasan Hutan Mutis Desa Bonle'u, Kecamatan Tobu Kabupaten Timor Tengah Selatan Nusa Tenggara Timur menyatakan bahwa terdapat 17 jenis tumbuhan paku. Jumlah yang tumbuhan paku di Hutan desa Tanglapui lebih banyak jumlah dengan yang ditemukan di Desa Bonleu, Kawasan Hutan Mutis. Meskipun Desa Bonleu berada di sekitar Gunung Mutis yang merupakan salah satu gunung tertinggi di Pulau Timor dan memiliki kondisi lingkungan yang mendukung keberadaan tFumbuhan paku. Hal ini menunjukkan kawasan hutan Desa Tanglapui memiliki kondisi lingkungan baik abiotik maupun biotik yang mendukung keberadaan jenis-jenis tumbuhan paku. Lingkungan hutan Desa Tanglapui dengan pepohonan yang tumbuh rapat dan kelembaban yang tinggi karena memiliki 5 aliran sungai. Menurut Wanma (2016) kanopi hutan yang rapat dan kondisi kelembaban yang tinggi merupakan kondisi lingkungan yang mendukung kehidupan tumbuhan. Dari berbagai jenis tumbuhan paku yang ditemukan di Hutan Desa Tanglapui spesies yang paling banyak 
ditemukan adalah Cyathea contaminans dengan jumlah 509 individu dan Diplazium esculentum sebanyak 128 individu sedangkan nilai kerapatan terendah yaitu Microsorum punctatum dengan jumlah sebanyak 3 individu. Tumbuhan paku ini yang paling dominan karena habitatnya terdapat pada tanah yang lembab seperti di pinggiran sungai, di bawah pohon yang paling rindang, sampai ke tempat-tempat yang kekurangan air, dan ada yang bertahan hidup dan beradaptasi di tempat yang cukup cerah dan kering.

2. Kerapatan, frekuensi dan indeks nilai penting dari masing-masing spesies tumbuhan paku.

Tabel 1. Kerapatan, Kerapatan Relatif, Frekuensi Relatif, dan Indeks Nilai Penting Tumbuhan Paku, di Hutan Desa Tanglapui

\begin{tabular}{|c|c|c|c|c|c|c|c|}
\hline No & Famili & Spesies & $\mathbf{K}$ & KR & $\mathbf{F}$ & FR & INP \\
\hline 1 & Athyriaceae & $\begin{array}{l}\text { Diplazium } \\
\text { esculentum }\end{array}$ & 0.078 & $13.87 \%$ & 0.375 & $7.69 \%$ & 21.56 \\
\hline 2 & Cyatheaceae & $\begin{array}{l}\text { Cyathea } \\
\text { contaminans }\end{array}$ & 0.318 & $56.07 \%$ & 0.875 & $17.94 \%$ & 74.01 \\
\hline 3 & Schizaceae & $\begin{array}{l}\text { Lygodium venustum } \\
\text { sw }\end{array}$ & 0.002 & $0.44 \%$ & 0.125 & $2.56 \%$ & 3 \\
\hline 4 & Pteridaceae & Drynaria quercifolia & 0.015 & $2.74 \%$ & 0.375 & $7.69 \%$ & 10.43 \\
\hline 5 & Polypodiaceae & $\begin{array}{l}\text { Platycerium } \\
\text { bifurcatum }\end{array}$ & 0.023 & $4.07 \%$ & 0.5 & $10.25 \%$ & 14.32 \\
\hline 6 & Polypodiaceae & $\begin{array}{l}\text { Microsorum } \\
\text { punctatum }\end{array}$ & 0.001 & $0.31 \%$ & 0.125 & $2.56 \%$ & 2.87 \\
\hline 7 & Equisetaceae & Equisetum debile & 0.023 & $4.07 \%$ & 0.375 & $7.69 \%$ & 11.76 \\
\hline 8 & Pteridaceae & Pteris biaurita L & 0.003 & $0.54 \%$ & 0.125 & $2.56 \%$ & 3.1 \\
\hline 9 & Pteridaceae & $\begin{array}{l}\text { Pytirogramma } \\
\text { calomelanos }\end{array}$ & 0.004 & $0.75 \%$ & 0.125 & $2.56 \%$ & 3.31 \\
\hline 10 & Polypodiaceae & $\begin{array}{l}\text { Polypodium } \\
\text { virginianum } \mathrm{L}\end{array}$ & 0.006 & $1.09 \%$ & 0.125 & $2.56 \%$ & 3.65 \\
\hline 11 & Aspleniaceae & Hymenasplenium sp & 0.016 & $2.96 \%$ & 0.25 & $5.12 \%$ & 8.08 \\
\hline 12 & Dryopteridaceae & Asplenium affine & 0.006 & $1.09 \%$ & 0.125 & $2.56 \%$ & 3.65 \\
\hline 13 & Pteridaceae & Adiantum cuneatum & 0.003 & $0.54 \%$ & 0.125 & $2.56 \%$ & 3.1 \\
\hline 14 & Marattiaceae & Pteris cretica L & 0.006 & $1.09 \%$ & 0.125 & $2.56 \%$ & 3.65 \\
\hline 15 & Davalliaceae & Davallia denticulate & 0.005 & $0.98 \%$ & 0.125 & $2.56 \%$ & 3.54 \\
\hline 16 & Aspleniaceae & $\begin{array}{l}\text { Asplenium } \\
\text { attenuatum }\end{array}$ & 0.008 & $1.53 \%$ & 0.125 & $2.56 \%$ & 4.09 \\
\hline 17 & Psilotaceae & Psilotum nudum L & $\begin{array}{r}0.003 \\
1\end{array}$ & $0.54 \%$ & 0.125 & $2.56 \%$ & 3.1 \\
\hline 18 & Marsileaceae & Marsilia polycarpa & $\begin{array}{r}0.013 \\
1 \\
\end{array}$ & $2.3 \%$ & 0.25 & $5.12 \%$ & 7.42 \\
\hline 19 & Pteridaceae & Pteris vittata & $\begin{array}{r}0.010 \\
6\end{array}$ & $1.86 \%$ & 0.125 & $2.56 \%$ & 4.42 \\
\hline 20 & Dryopteridaceae & $\begin{array}{l}\text { Nephrolepis } \\
\text { biserrata }\end{array}$ & $\begin{array}{r}0.005 \\
6\end{array}$ & $0.98 \%$ & 0.125 & $2.56 \%$ & 3.54 \\
\hline 21 & Polypodiaceae & $\begin{array}{l}\text { Pyrrosia } \\
\text { piloselloidesi L M.G }\end{array}$ & $\begin{array}{r}0.003 \\
7\end{array}$ & $0.65 \%$ & 0.125 & $2.56 \%$ & 3.2 \\
\hline
\end{tabular}




\begin{tabular}{ccccccccc}
\hline 22 & Thelypteridaceae & $\begin{array}{l}\text { Macrothelipteris } \\
\text { torresiana }\end{array}$ & 0.008 & $1.42 \%$ & 0.125 & $2.56 \%$ & 3.98 \\
\hline Jumlah & & 0.567 & $99.89 \%$ & 4.875 & 99.9 & $\%$ & 99.10 \\
\hline
\end{tabular}

Tabel 1 menggambarkan nilai kerapatan, kerapatan relatif, frekuensi, frekuensi relatif, dan indeks nilai penting dari 22 spesies tumbuhan paku yang ditemukan. Cyathea contaminans merupakan spesies yang paling banyak ditemukan dengan jumlah 509 individu sedangkan Microsorum punctatum merupakan spesies yang paling sedikit ditemukan dengan jumlah sebanyak 3 individu. Pembahasan mengenai kerapatan, frekuensi dan indeks nilai penting dari tumbuhan paku dijelaskan secara terpisah pada sub-bab berikut:

\section{a. Kerapatan}

Jenis tumbuhan paku dengan nilai kerapatan tinggi merupakan jenis tumbuhan dengan jumlah individu lebih banyak dalam suatu unit luas tertentu sedangkan jenis tumbuhan dengan nilai kerapatan rendah memiliki jumlah individu yang lebih sedikit pada skala luas yang sama. Hal ini dipengaruhi oleh kondisi lingkungan sekitar, serta adanya persaingan antara jenis untuk mendapatkan ruang, nutrisi dan cahaya Syahbudin dalam Syafrudin dkk (2016). Berdasarkan hasil perhitungan nilai kerapatan jenis tumbuhan paku yang memiliki nilai kerapatan tertinggi yaitu Cyathea contaminans dan Diplazium esculentum. Spesies Cyathea contaminans dengan jumlah 509 individu, dengan nilai kerapatan diperoleh sebesar $0.31 / \mathrm{m}^{2}$ dan nilai kerapatan relatif sebesar $56.07 \%$. Nilai kerapatan relatif tersebut dapat diartikan bahwa lebih dari setengah total kerapatan tumbuhan paku yang ada di Hutan Tanglapui merupakan jenis Cyathea contaminans. Dapat dikatakan bahwa Hutan Desa Tanglapui merupakan habitat yang sesuai bagi pertumbuhan Cyathea contaminans. Kondisi lingkungan Hutan Tanglapui seperti tanah yang lembab karena aliran sungai yang melalui hutan ini, suhu rendah dengan kelembaban udara yang tinggi sesuai untuk menunjang kehidupan Cyathea contaminans. Sesuai dengan pendapat Suin (2002) menyatakan kelembapan dan suhu yang sesuai dapat membuat jenis tertentu tumbuh dan berkembangbiak dengan baik. Tingginya nilai kerapatan dan kerapatan relatif Cyathea contaminans disebabkan oleh pertumbuhan yang baik, selain itu adaptasi dan kompetisi yang baik juga menjadi faktor yang mendukung tingginya penyebaran Cyathea contaminans di Hutan Tanglapui. Menurut Hartini (2006) dalam penelitian tumbuhan paku Di Cagar Alam Sago Melintang, Sumatra Barat dan aklimatisasinya di Kebun Raya Bogor menyatakan bahwa Cyathea contaminans tersebar di seluruh kawasan yang diamati mulai dari 1.060-1.240 m dpl. Biasanya terdapat di hutan yang telah dibuka dan di tempat-tempat yang terbuka, khususnya di dekat sungai. Jenis ini ditemukan pada ketinggian 200-1.600 m dpl. Sesuai pada kawasan Hutan Tanglapui yang banyak terdapat tempat-tempat terbuka dan terdapat aliran sungai. Habitat tumbuh dari spesies ini pada hutan Tanglapui kebanyakan tumbuh pada tempat yang terbuka dan juga tumbuh pada tepi aliran sungai. Ada juga yang terdapat tumbuh pada tempat naungan namun memiliki jumlah individu yang sedikit.

Nilai kerapatan tertinggi kedua adalah Diplazium esculentum dengan nilai kerapatannya sebanyak $0.07 / \mathrm{m}^{2}$. Dari jumlah nilai kerapatan Diplazium esculentum ini sehingga mendapatkan nilai kerapatan relatifnya sebesar $13.87 \%$. Spesies Diplazium esculentum ini biasanya masyarakat Desa Tanglapui memanfaatkan sebagai sayur untuk bahan konsumsi secara rutin. Menurut Purnawati dkk (2014) menyatakan bahwa Diplazium esculentum ditemukan di hutan kerangas dan rawa. Umumnya hidup di tempat terbuka yang mendapat sinar matahari langsung dan teduh dengan pencayaan mahatari kurang dan bisa juga dimanfaatkan sebagai sayur. Hal ini sesuai dengan kondisi tanah 
pada kawasan Hutan Tanglapui yang lembab dan berawa dan spesies Diplazium esculentum ini ditemukan tumbuh pada kondisi tanah yang lembab dan berawa. Microsorum punctatum merupakan jenis tumbuhan paling sedikit jumlah individu diantara 22 spesies yang ditemukan pada lokasi penelitian. Dengan jumlah sebanyak 3 individu, yang ditemukan dalam 1 plot pengamatan pada stasium empat, sehingga dengan hasil perhitungan diperoleh nilai kerapatan sebesar $0.0018 / \mathrm{m}^{2}$, sedangkan kerapatan relatifnya sebesar $0.31 \%$. Kecilnya nilai kerapatan relatif ini disebabkan pada spesies Microsorum punctatum yang memiliki jumlah individu yang sedikit dan jenis ini kurang mampu beradaptasi dengan lingkungan dan faktor abiotik yang tidak mendukung pertumbuhan tumbuhan paku ini. Sehingga jumlah individu, kerapatan dan kerapatan relatif dari spesies ini sangatlah rendah diantara jenis tumbuhan paku yang lain. Hal ini sesuai dengan pendapat Partomihardjo dalam Hariyadi (2000) penyebaran epifit pada setiap pohon lebih dipengaruhi oleh sinar matahari. Selain itu menurut Azemi, dkk, dalam Hariyadi (2000), variasi epifit lebih disebabkan oleh perbedaan kondisi iklim mikro. Masing-masing strata pohon memiliki iklim mikro yang berbeda.

\section{b. Frekuensi}

Berdasarkan Tabel 1 terlihat jenis tumbuhan paku Cyathea contaminans mempunyai nilai frekuensi tertinggi yang ditemukan pada kawasan Hutan Tanglapui sebesar 87,25 \%. Tingginya nilai frekuensi spesies Cyathea contaminans dikarenakan hampir selalu ditemukan pada setiap petak pengamatan yaitu dalam 7 plot dari 8 plot pengamatan pada setiap stasium. Hal ini dipengaruhi oleh faktor lingkungan yang sangat baik atau sesuai untuk pertumbuhan Cyathea contaminans sehingga dapat ditemukan pada setiap lokasi petak pengamatan di Hutan Tanglapui. Menurut Syahbudin dalam Syafrudin dkk (2016) menyatakan bahwa tingginya frekuensi ini disebabkan lingkungan dan sifat distribusi suatu jenis tumbuhan tertentu yang memungkinkan untuk tumbuh dengan baik sehingga lebih sering muncul pada sejumlah petak atau plot pengamatan. Nilai frekuensi relatif (FR) yang tinggi pada suatu jenis tumbuhan, frekuensi masingmasing jenis merupakan gambaran presentase penyebaran suatu jenis tumbuhan pada suatu areal, daya tumbuh biji dan faktor abiotik lingkungan. Dengan demikan jenis tersebut akan tersebar merata pada seluruh lokasi penelitian.Nilai frekuensi relatif rendah yang berkisaran dari $2.56 \%-10.25 \%$ atau di bawah dari $17.69 \%$ yaitu Platycerium bifurcatum dengan nilai frekuesi relatifnya sebesar $10.25 \%$. Jenis tumbuhan paku dengan nilai frekuensi relatif sebesar $7.69 \%$ antara lain Diplazium esculentum, Drynaria quercifolia, dan Equisetum debile. Jenis tumbuhan paku yang nilai frekuensi relatifnya berkisar antara $5.12 \%$ yaitu jenis Marsilia polycarpa dan Hymenasplenium sp. kemudian jenis yang mempunyai nilai frekuensi relatif terendah sebesar $2.56 \%$ yaitu diantaranya adalah Lygodium venustum sw, Microsorum punctatum, Pteris biaurita L, Pytirogramma calomelanos, Polypodium virginianum L, Hymenasplenium sp, Asplenium affine, Adiantum cuneatum, Pteris cretica L, Davallia denticulata, Asplenium attenuatum, Psilotum nudum L, Pteris vittata, Nephrolepis biserrata, Pyrrosia piloselloidesi L M.G, dan Macrothelipteris torresiana. Hal ini disebabkan jenis tersebut kurang mampu bersaing dan beradaptasi dengan lingkungan sehingga memiliki nilai frekuensi relatif yang rendah.

\section{c. Indeks nilai penting (INP)}

Dari hasil perhitungan indeks nilai penting (INP) yang disajikan dalam Tabel 1 memperlihatkan bahwa spesies yang memiliki INP tertinggi di lokasi penelitian Hutan Desa Tanglapui adalah Cyathea contaminans dengan nilai INP sebesar 74.01. Nilai INP Cyathea contaminans yang tinggi ini, memperlihatkan tumbuhan ini sangat dominan di 
Hutan Desa Tanglapui. Tingginya nilai INP dari spesies ini dikarenakan tumbuhan paku tersebut tersebar luas pada kawasan hutan Tanglapui. Banyaknya penyebaran individu dari spesies Cyathea contaminans tersebut di temukan dalam 7 plot dari 8 plot pengamatan pada empat stasiun, dengan jumlah individu sebanyak 509. Hasil perhitungan dengan nilai INP terendah yaitu spesies Microsorum punctatum. Jenis tumbuhan paku ini memiliki nilai INP sebesar 2.87. Kecilnya presentase nilai INP dari spesies tersebut dikarenakan berdasarkan hasil penelitian pada kawasan hutan desa Tanglapui, spesies ini sangat sedikit jumlah penyebaran individu pada lokasi penelitian. Sedikitnya jumlah penyebaran spesies ini hanya ditemukan dalam 1 plot pengamatan pada stasium empat dengan jumlah sebanyak 3 individu. Sedikitnya jumlah spesies ini berpengaruh pada pada presentase nilai INP dari jenis Microsorum punctatum, sehingga memiliki nilai INP terendah diantara 22 spesies tumbuhan paku yang ditemukan pada kawasan Hutan Tanglapui. Jenis tumbuhan paku yang memiliki INP yang rendah terjadi karena jenisjenis tumbuhan paku kurang mampu beradaptasi dengan lingkungan yang terdapat pada kawasan hutan Desa Tanglapui. Kurangnya kompetitifnya jenis tumbuhan paku dengan jenis tumbuhan paku yang lain mengakibatkan pertumbuhan mereka menjadi terbatas. Hal ini sesuai dengan pendapat Indriyanto (2009) bahwa jenis tumbuhan paku yang mampu beradaptasi dengan baik maka keberadaannya dapat mendominasi pada suatu lokasi.

\section{Keanekaragaman Tumbuhan Paku di Hutan Desa Tanglapui}

Berdasarkan Tabel 2 hasil perhitungan indeks keanekaragaman jenis ShanonWienner bahwa spesies paku dikawasan hutan Desa Tanglapui menunjukan nilai keanekaragaman sebanyak -0.77. Berdasarkan ketetapan nilai Shanon-Wienner menyatakan jika nilai keanekaragaman $\mathrm{H}^{\prime}<3$ maka indeks keanekaragamannya rendah, sebaliknya jika nilai keanekaragamaan $\mathrm{H}^{\prime}>3$ menunjukan bahwa keanekaragaman spesies pada lokasi tersebut melimpah tinggi. Hal ini menunjukan bahwa komunitas tumbuhan paku di kawasan hutan Desa Tanglapui memiliki nilai indeks keaanekaragaman yang sangat rendah karena $\mathrm{H}^{\prime}<3$. Rendahnya keanegaragaman jenis paku yang ada di kawasan Hutan Tanglapui itu disebabkan di antara 22 jenis tumbuhan paku yang ditemukan, terdapat salah satu yang mendominasi lokasi hutan tersebut yaitu spesies Cyathea contaminans. Jenis Cyathea contaminans ini tersebar luas pada areal lokasi penelitian yang ditemukan dalam 7 plot pengamatan. Jenis ini memiliki nilai kerapatan yang sangat tinggi yaitu sebanyak $0.31 / \mathrm{m}^{2}$ dari 22 jenis paku yang ditemukan. Hal ini sesuai dengan pendapat Leksono (2007) keanekaragaman spesies dapat digunakan untuk menentukan struktur komunitas. Semakin banyak jumlah spesies dengan tingkat jumlah individu yang sama atau mendekati sama, semakin tinggi tingkat heterogennya. Sebaliknya, jika jumlah spesies sangat sedikit, dan terdapat perbedaan jumlah individu yang besar antar spesies maka semakin rendahlah heterogenitas suatu komunitas. Banyaknya individu dari jenis Cyathea contaminans memperhambat pertumbuhan pada jenis tumbuhan paku yang lain dalam bersaing untuk mendapat ruang, nutrisi, dan cahaya. Dibandingkan dengan penelitian terdahulu yang dilakukan oleh Syafrudin, dkk, (2016), tentang keanekaragaman dan potensi paku (Pteridophyta) di Taman Nasional Gunung Gede Panggrango Cianjur (TNGGP). Berdasarkan penjelasannya bahwa keanekaragaman tumbuhan paku di Taman Naisional Gunung Gede Panggrango Cianjur (TNGGP) masih rendah karena nilai keanekaragaman jenis tumbuhan paku berada pada kisaran 0,93-1,48, berarti komunitas tumbuhan paku di Taman Naisional Gunung Gede Panggrango Cianjur (TNGGP) memiliki kompleksitas yang rendah. Rendahnya keanekaragaman tumbuhan 
paku di kawasan Tanglapui hal tersebut dipengaruhi pada perbedaan ketinggian dan faktor lingkungan sekitar sehingga berpengaruh pada pertumbuhan tumbuhan paku.

Tabel 2 Nilai Indeks Keanekaragaman Jenis Shanon-Wienner Spesies Tumbuhan Paku di Hutan Desa Tanglapui.

\begin{tabular}{|c|c|c|c|c|c|}
\hline No & Spesies & $\begin{array}{c}\text { Jumlah } \\
\text { (ni) }\end{array}$ & $\mathrm{ni} / \mathrm{N}$ & $\log n i / N$ & ni/N.log ni/N \\
\hline 1 & $\begin{array}{l}\text { Diplazium } \\
\text { esculentum }\end{array}$ & 128 & 0.140 & -0.852 & -0.119 \\
\hline 2 & $\begin{array}{l}\text { Cyathea } \\
\text { contaminans }\end{array}$ & 509 & 0.558 & -0.252 & -0.141 \\
\hline 3 & $\begin{array}{l}\text { Lygodium venustum } \\
\text { sw }\end{array}$ & 4 & 0.004 & -2.357 & -0.010 \\
\hline 4 & Drynaria quercifolia & 25 & 0.027 & -1.561 & -0.042 \\
\hline 5 & Platycerium $S p$ & 37 & 0.040 & -1.391 & -0.056 \\
\hline 6 & $\begin{array}{l}\text { Microsorum } \\
\text { punctatum }\end{array}$ & 3 & 0.003 & -2.482 & -0.008 \\
\hline 7 & Equisetum debile & 37 & 0.040 & -1.391 & -0.056 \\
\hline 8 & Pteris tripartite & 5 & 0.005 & -2.260 & -0.012 \\
\hline 9 & $\begin{array}{l}\text { Pytirogramma } \\
\text { calomelanos }\end{array}$ & 7 & 0.007 & -2.114 & -0.016 \\
\hline 10 & $\begin{array}{l}\text { Polypodium } \\
\text { virginianum L }\end{array}$ & 10 & 0.010 & -1.959 & -0.021 \\
\hline 11 & Hymenasplenium sp & 27 & 0.029 & -1.528 & -0.045 \\
\hline 12 & Asplenium affine & 10 & 0.010 & -1.959 & -0.021 \\
\hline 13 & Adiantum cuneatum & 5 & 0.005 & -2.260 & -0.012 \\
\hline 14 & Pteris cretica $L$ & 10 & 0.010 & -1.959 & -0.021 \\
\hline 15 & Davallia denticulate & 9 & 0.009 & -2.005 & -0.019 \\
\hline 16 & $\begin{array}{l}\text { Asplenium } \\
\text { attenuatum }\end{array}$ & 14 & 0.015 & -1.813 & -0.027 \\
\hline 17 & Psilotum nudum L & 5 & 0.005 & -2.260 & -0.012 \\
\hline 18 & Marsilia polycarpa & 21 & 0.023 & -1.637 & -0.037 \\
\hline 19 & Pteris vittata & 17 & 0.018 & -1.729 & -0.032 \\
\hline 20 & $\begin{array}{l}\text { Nephrolepis } \\
\text { biserrata }\end{array}$ & 9 & 0.009 & -2.005 & -0.019 \\
\hline 21 & $\begin{array}{l}\text { Pyrrosia } \\
\text { piloselloides L M.G. }\end{array}$ & 6 & 0.006 & -2.181 & -0.014 \\
\hline \multirow[t]{2}{*}{22} & $\begin{array}{l}\text { Macrothelipteris } \\
\text { torresiana }\end{array}$ & 13 & 0.014 & -1.845 & -0.026 \\
\hline & $\begin{array}{l}\text { Jumlah total } \\
\text { keseluruhan }\end{array}$ & 911 & & & -0.776 \\
\hline
\end{tabular}

\section{KESIMPULAN DAN SARAN}

\section{Kesimpulan}

a. Dari hasil penelitian yang dilaksanakan di kawasan Hutan Desa Tanglapui, Kecamatan Alor Timur Kabupaten Alor, ada 22 jenis tumbuhan paku yang 
ditemukan yaitu Diplazium esculentum, Cyathea contaminans, Lygodium venu stum sw, Drynaria quercifolia, Platycerium bifurcatum, Microsorum punctatum, Equisetum debile, Pteris biaurita L, Pytirogramma calomelanos, Polypodium virginianum L, Hymenasplenium sp, Asplenium affine, Adiantum cuneatum, Pteris cretica L, Davallia denticulate, Asplenium attenuatum, Psilotum nudum L, Marsilia polycarpa, Pteris vittata, Nephrolepis biserrata, Pyrrosia piloselloidesi L M.G, Macrothelipteris torresiana.

b. Salah satu tumbuhan paku tersebut yang mendomisi kawasan hutan Tanglapui yaitu spesies Cyathea contaminans dengan jumlah sebanyak 509 individu dengan nilai kerapatannya relatif sebesar 56,78\% Tingginya nilai kerapatan relatif suatu spesies tersebut berpengaruh pada nilai keanekaragaman total tumbuhan paku di Hutan Desa Tanglapui yaitu sebesar 0.77 , sehingga masuk kategori rendah.

\section{Saran}

Bagi para peneliti yang ingin melakukan penelitian lanjutan agar dapat meneliti tentang etnobotani tumbuhan paku (Pteridophyta) bagi masyarakat Desa Tanglapui.

\section{DAFTAR PUSTAKA}

Alghifari, S. 2016. Keanekaragaman Jenis Paku Terestrial dikawasan Gunung Bunder Taman Nasional Gunung Halimn Salak (Bogor) Jawa Barat. Skripsi. Institut Pertanian Bogor : Bogor.

Arini, D.I.D \& Kinho, J. 2012. Keragaman Jenis Tumbuhan Paku (Pteridophyta) di Cagar Alam Gunung Ambang Sulawesi Utara. Info BPK Manado 2(1): 17-40.

Hariyadi, B. 2000. Sebaran dan Keanekaragaman Jenis Tumbuhan Paku di Bukit Sari, Jambi (tesis). Bandung ITB.

Hartini, R., 2006. Tumbuhan paku di Cagar Alam Sago Malintang, Sumatra Barat dan Aklimatisasinya di Kebun Raya Bogor. Biodiversitas 7 (3) : .

Imaniar, R., Pujiastuti, \& Murdiyah, S. 2017. Identifikasi Keanekaragaman Tumbuhan Paku Di Kawasan Air Terjun Kapas Biru Kecamatan Pronojiwo Kabupaten Lumajang Serta Pemanfaatannya Sebagai Booklet. Jurnal Pendidikan Biologi 6 (3) : 337-345. DOI: https://doi.org/10.24114/jpb.v6i3.7901

Indriyanto. 2009. Ekologi Hutan. Jakarata: Bumi Aksara.

Leksono, A. 2017. Ekologi pendekatan deskriptif dan kuantitatif. Bayumedia publishing : malang.

Liem, Y. 2011. Jenis-Jenis Tumbuhan Paku (Pteridophyta) Di Kawasan Hutan Mutis Desa Bonle'u Kecamatan Tobu Kabupaten Timor Tengah Selatan. Skripsi. FKIP Biologi Universitas Kristen Artha Wacana Kupang.

Musriadi., Jailani., \& Armi. 2017 Identifikasi Tumbuhan Paku (Pteridophyta) Sebagai Bahan Ajar Botani Tumbuhan Rendah Di Kawasan Tahura Pocut Meurah Intan Kabupaten Aceh Besar. Jurnal pendidikan sains Universitas Muhammadiyah Semarang 5(1) : 22-31. DOI: https://doi.org/10.26714/jps.5.1.2017.22-31

Mulyatin, T. 2016. Identifikasi Tumbuhan Paku (Pteridophyta) di Kawasan Pulau Sumba Nusa Tenggara Timur Sebagai Sumber Belajar Biologi. thesis, University of Muhammadiyah Malang 
Purnawati, U., Turnip, M., \& Lovadi, I. 2014. Eksplorasi Paku-Pakuan (Pteridophyta) Di Kawasan Cagar Alam Mandor Kabupaten Landak. Jurnal Protobiont 3 (2) : 155165.

Ruma, M., \& Nomnafa, D. 2016. "Keanekaragaman Jenis Tumbuhan Paku (Pteridophyta) Di Oehala Desa Oelekam Timor Tengah Selatan”. Jurnal MIPA Penelitian Dan Pengembangan (JMIPA), 14(1) : 49-60

Sanginés-Franco, C., Luna-Vega, I, Ayala, O.A., \& Contreras-Medina, R. 2011. Distributional Patterns and Biogeographic Analysis of Ferns in the Sierra Madre Oriental, Mexico. American Fern Journal, 101(2):81-104. DOI: http://dx.doi.org/10.1640/0002-8444-101.2.81

Simpson, M.G. 2006. Plant Systematics. Elsevier Academic Press: New York

Suin, N. M. 2002. Metode Ekologi. Universitas Andalas : Padang.

Syafrudin, Y., Haryani, T, S., \& Wiedarti, S., 2016. Keanekaragaman dan Potensi Paku (Pteridophyta) di Taman Naisional Gunung Gede Panggrango Cianjur (TNGGP). Ekologia 6 (2) : 24-31.

Wanma, A.O. 2016. Keanekaragaman Jenis Tumbuhan Paku (Pteridophyta) Di Gunung Arfak Papua Barat. Tesis. Institut Pertanian Bogor : Bogor.

Yuliastuti, E., Herawatiningsih, R., \& Wahdina. 2014. Keanekaragaman Jenis Tumbuhan Paku-Pakuan (Pteridophyta) Di Desa Bemban Kawasan Hutan Lindung Gunung Ambawang Kecamatan Kubu Kabupaten Kubu Raya. Jurnal hutan lestari : 198206 